\title{
Effects of Delayed Pubertal Development, Nutritional Status, and Disease Severity on Longitudinal Patterns of Growth Failure in Children With Sickle Cell Disease
}

\author{
BABETTE S. ZEMEL, DEBORAH A. KAWCHAK, KWAKU OHENE-FREMPONG, JOAN I. SCHALL, \\ AND VIRGINIA A. STALLINGS
}

\begin{abstract}
Divisions of Gastroenterology, Hepatology, and Nutrition [B.S.Z., D.A.K., J.I.S., V.A.S.] and Hematology [K.O.-F.], The Children's Hospital of Philadelphia, Department of Pediatrics, University of Pennsylvania School of Medicine, Philadelphia,
\end{abstract} Pennsylvania 19104

\begin{abstract}
Previous studies of children with sickle cell disease (SCD) reported poor growth and delayed maturation. However, the prevalence, magnitude, and correlates of suboptimal growth remain poorly understood. A prospective longitudinal study was undertaken to determine the effects of disease severity and nutritional status on growth, an indicator of childhood well-being. Children, birth to $18 \mathrm{y}$ of age, with SCD-SS were evaluated annually for $4 \mathrm{y}$. Growth, nutritional status, skeletal and sexual maturation, disease severity, dietary intake, and maternal education were assessed. In this sample of 148 children ( 78 females), growth in height, weight, or body mass index declined in $84 \%$ of subjects; $38 \%$ fell below the 5 th percentile in one or more measures. Puberty was delayed 1 to $2 \mathrm{y}$, and median age at menarche was $13.2 \mathrm{y}$. Skeletal age was delayed by $0.7 \pm 1.4 \mathrm{y}$ overall and by $1.3 \pm 1.5 \mathrm{y}$ in children 10 to $15 \mathrm{y}$ old. Height status declined over time and was positively associated with advancing puberty and hematological measures in girls, and nutritional status in girls and boys. Growth failure and maturational delay remain significant chronic problems in children with SCD-SS and are related to potentially modifiable factors such as nutritional status. (Pediatr Res 61: 607-613, 2007)
\end{abstract}

$\mathrm{S}$ udies of children with SCD from the 1960s to 1990s described poor growth and delayed skeletal and sexual maturation (1-5), demonstrating low growth percentiles in height and weight among children older than 2 to $5 \mathrm{y}$ of age, especially for children with type SCD-SS. Among studies conducted in the United States, only one was longitudinal (1), documenting short stature, poor weight gain, and delayed adolescent growth, particularly among males with SCD. The results of the Comprehensive Study of Sickle Cell Disease (CSSCD) (4), reporting on more than 2000 patients, confirmed many of these findings and showed that growth failure was unrelated to socioeconomic status, the onset and progression through puberty were delayed, and delayed menarche in girls was related to their low weight status. However, further effects

Received May 3, 2006; accepted December 6, 2006.

Correspondence: Babette Zemel, Ph.D., Division of GI and Nutrition, The Children's Hospital of Philadelphia, 3535 Market Street, Room 1560, Philadelphia, PA 19104; e-mail: zemel@email.chop.edu

Supported by the General Clinical Research Center (NIH/NCRR grant M01RR00240), the Comprehensive Sickle Cell Center (NIH HL 38633), and the Nutrition Center of the Children's Hospital of Philadelphia.

DOI: 10.1203/pdr.0b013e318045bdca of disease related factors on growth failure were not investigated.

There has been a paucity of studies designed to identify the causes of and treatment strategies for suboptimal growth and pubertal delay in SCD. Advances in the clinical care of children with SCD, such as earlier diagnosis, penicillin prophylaxis, folate supplementation, and transfusion and hydroxyurea therapy, have reduced morbidity and mortality. However, the prevalence of suboptimal growth and its relationship to disease severity has not been evaluated in a contemporary cohort of U.S. children. Growth status remains an important indicator of the overall health and well-being of the child. We hypothesized that nutritional status and disease severity were significant predictors of growth failure assessed prospectively in children with SCD-SS. The present study describes longitudinal patterns of growth in a group of children with SCD cared for in a comprehensive sickle cell center and identifies potentially remediable factors associated with suboptimal growth.

\section{METHODS}

Subjects. All eligible children with SCD-SS receiving care at a comprehensive sickle cell center were invited to participate. Children ages birth to $18 \mathrm{y}$ were eligible if they did not have other significant chronic illnesses (e.g. cystic fibrosis, moderate to severe cerebral palsy, Down syndrome), were not taking medications known to affect growth or nutritional status (e.g. growth hormone, glucocorticoid therapy), and were not taking hydroxyurea. Children receiving chronic transfusion therapy after a stroke were included. SCD-SS genotype was determined by standard hemoglobin $(\mathrm{Hgb})$ separation studies including electrophoresis and high-pressure liquid chromatography. The study protocol was approved by the Committee for the Protection of Human Subjects of The Children's Hospital of Philadelphia. Informed consent was obtained from parents or guardians and assent from children ages $7 \mathrm{y}$ and older.

Procedures. Children were evaluated at baseline (visit 1) and annually for 4 y (visits 2-5) in conjunction with a regularly scheduled office visit. A research anthropometrist obtained measurements of length or stature using an infantometer or digital stadiometer (Holtain, Crymych, UK), weight using an infant or stand-on digital electronic scale (Scaletronix, White Plains, NY), mid-upper arm circumference, and skinfold thicknesses at the triceps, biceps, subscapular, and suprailiac sites using skinfold calipers (Holtain, Crymych, UK) following standard techniques (6).

Abbreviations: CSSCD, Comprehensive Study of Sickle Cell Disease; Hct, hematocrit; Hgb, hemoglobin; NHANES III, Third National Health and Nutrition Examination Survey; SCD, sickle cell disease 
Puberty status was determined using a self-assessment questionnaire (7) that contained pictorial representations and written descriptions of Tanner's stages of breast, genital, and pubic hair development (8). This method has previously been validated in our laboratory (9). Menarcheal status and age at first menstruation information was elicited from girls, $9 \mathrm{y}$ of age and older. Bone age, determined at visit 2 from a left hand-wrist radiograph, was assessed by a single investigator (B.S.Z.) using the Tanner Whitehouse III method (10). Bone age delay (years) was calculated as bone age minus chronological age.

Blood samples were analyzed for Hgb concentration, hematocrit (Hct), reticulocyte count, fetal $\mathrm{Hgb}$ level (HgbF) (visits 3-5 only), and platelet and white blood cell (WBC) counts (Clinical Laboratory, Children's Hospital of Philadelphia). For children receiving long-term transfusion therapy, blood samples were obtained just before transfusion. For statistical analyses, hematological indices and nutritional status $Z$ scores (arm circumference, triceps and upper arm fat area $Z$ scores) were transformed to eliminate skewness, but the results with the nontransformed values are shown. Dietary intake was obtained at visits 2 through 5 using the 24-h recall method and computer analyzed (Food Processor, ESHA Research, Inc., Salem, OR). Total energy intake, protein intake, and percentage of energy from fat were determined. Transfusion status, health history, and family information, including education status of the primary caretaker and household income were elicited by questionnaire. Because many families did not know their annual household income, only the education status of the primary caretaker (hereafter, maternal education) was used in the analyses. Number of SCD-related hospitalizations and total days of hospitalization in the year before and after each study visit were provided by the Comprehensive Sickle Cell Center database.

Statistical analysis Standard deviation (SD) scores ( $Z$ scores) and percentile rank for length, height, weight, and body mass index (BMI) were based on U.S. growth charts (11). Growth failure was defined as a height, weight, or BMI measurement below the 5th percentile. Upper arm muscle area and upper arm fat area were derived from the mid-upper arm circumference and triceps skinfold thickness measures (12). Z scores for arm circumference, triceps skinfold thickness, upper arm muscle area, and upper arm fat area were based on National Center for Health Statistics reference data (12).

Means and SDs were calculated using the XTSUM feature in STATA 9.0 (College Station, TX) to account for the mixed longitudinal design and repeat observations. Cross-sectional comparisons were performed using $t$ test for normally distributed data, and by the Mann-Whitney test for skewed data. Median age at menarche and at entry into the Tanner stages of sexual development (pubic hair and breast or genital development) was computed using the XTPROBIT feature in STATA.

Longitudinal analyses of growth $Z$ scores were performed using the longitudinal mixed effects analysis procedure in STATA (XTREG). Basic models were tested separately by gender to determine age trends, changes over time, and the effect of puberty. Additional variables were added to the model to determine whether puberty disease severity indicators (Hgb concentration, Hct, fetal HgbF level, hospitalizations, transfusion status, WBC counts), dietary intake (energy, protein, percentage of energy from fat), or maternal education were significantly associated with changes in growth status over time. For height $Z$ score, nutritional status (upper arm muscle area $Z$, upper arm fat area $Z$ ) variables were added to the models. Children receiving transfusion therapy were excluded from some analyses because of the known effects of transfusion therapy on the hematological indices of disease severity. Final models were selected on the basis of maximum $R^{2}$ values. Only the results from the final models are shown.

\section{RESULTS}

Sample description. One hundred forty-eight children (78 females), ages birth to $18 \mathrm{y}$, with SCD-SS were enrolled and evaluated annually for $4 \mathrm{y}$. The total number of visits was 578 . The average annual attrition rate was $12 \%$ per year over $4 \mathrm{y}$. Children who dropped out of the study were significantly older at baseline than those who remained enrolled (9.7 versus $6.3 \mathrm{y}, p<0.0001)$. However, they did not differ in growth pattern, hematological status, or maternal education level.

At baseline, $11 \%$ of subjects $(n=17)$ were receiving long-term blood transfusion therapy. In the final year, $16 \%$ of the sample $(n=14)$ received long-term blood transfusion therapy. Children who received transfusion therapy were $1.4 \mathrm{y}$ older, on average $(p<0.01)$, and, as expected, had higher Hgb
(9.0 versus $7.9 \mathrm{mg} / \mathrm{dL}, p<0.001)$ and Hct (26 versus $23 \%, p<$ 0.001 ) levels, and lower HgbF levels (2.2 versus 9.8\%, $p<$ $0.001)$ than those not receiving transfusion therapy. However, they did not differ in growth status as indicated by height, weight, or BMI $Z$ scores.

Skeletal and sexual maturation. Bone age was determined for 106 subjects (51 females) at the second visit, representing $78 \%$ of those who returned for the second visit. Those who completed the bone age evaluation were more likely to be older (9.3 versus $7.0 \mathrm{y}, p=0.02)$ and male ( $87 \%$ of males versus $71 \%$ of females, $p=0.02$ ), but they did not differ in disease severity measures, growth or nutritional status, or maternal education. The median bone age delay was $-0.4 \mathrm{y}$ [interquartile range (IQR): -1.67 to $0.4 \mathrm{y}$ ). For children 10 to $15 \mathrm{y}$ of age $(n=33)$, the median bone age delay was $-1.3 \mathrm{y}$ (IQR, -2.4 to $0.1 \mathrm{y}$ ). In this older age range, boys had a greater delay in bone age than girls $(-1.7 \pm 1.4 \mathrm{y}$ versus $-0.6 \pm$ $1.5 \mathrm{y}$, respectively, $p=0.04$ ). On average, the delay in bone age was less among children receiving transfusion therapy compared with those who did not, particularly in the 10- to 15 -y age range (median: -0.3 versus $-1.8, p=0.04$ ).

Puberty status was also delayed (Table 1). For girls, median age at menarche was $13.2 \mathrm{y}$. The median age of girls in stages 2 through 4 for breast stage and pubic hair development was 1 to 2 y delayed in comparison to recently published data from the National Health and Nutrition Examination Survey (NHANES) III (13) for non-Hispanic black children. For boys, a similar pattern of delay was observed for genital and pubic hair development. The median ages of children in Tanner stages 2-4 were similar to those reported by the CSSCD. Transfusion status did not have a notable effect on pubertal development.

Disease severity indicators and growth status. Hgb concentration, Hct, and $\mathrm{HgbF}$ level were in the range typically seen for children with SCD-SS. Excluding children receiving transfusion therapy, boys had lower Hct and HgbF levels than girls (Table 2). For the group overall (including subject receiving transfusion therapy), growth status was poor as indicated by the $Z$ scores for height, weight, and BMI (Table 2). Boys had significantly lower $Z$ scores for weight, length/ height, arm circumference, arm muscle area, and arm fat area than girls. Transfusion status was not associated with growth status, but boys receiving transfusion therapy had significantly greater mid-upper arm circumference (median: -0.6 versus $-1.5, p=0.02$ ) and upper arm fat area (median: -0.5 versus $-1.3, p=0.01) Z$ scores compared with other boys.

For all children, the percentage of subjects who exhibited growth failure ( $\leq 5$ th percentile) at any time during the study was $26 \%, 22 \%$, and $24 \%$, for weight, height, and BMI, respectively (Fig. 1). Thirty-eight percent of subjects exhibited growth failure at any time for any of the three growth measures. Boys were more likely to have growth failure than girls for all measures. Moreover, the majority of children failed to maintain their growth status established at visit 1 and experienced a negative change in growth $Z$ scores. From study entry to the last visit, $70 \%$ of children declined in length/ height $Z$ score, 59\% declined in weight $Z$ score, and 55\% 
Table 1. Tanner stages in boys and girls with SCD compared with non-Hispanic blacks in NHANES III

\begin{tabular}{|c|c|c|c|c|c|c|c|}
\hline & \multirow[b]{2}{*}{ Stage } & \multicolumn{4}{|c|}{ Children with SCD* } & \multirow{2}{*}{$\begin{array}{l}\text { Children with SCD: } \\
1979 \text { to } 1982 \dagger(4) \\
\text { Median age at entry, y }\end{array}$} & \multirow{2}{*}{$\begin{array}{l}\text { NHANES III } \ddagger \text { (13) } \\
\text { Median age at entry, y }\end{array}$} \\
\hline & & Median age at entry, $y$ & Range & Obs. & No. & & \\
\hline \multicolumn{8}{|c|}{ Breast or genital stage } \\
\hline \multirow[t]{4}{*}{ Females } & 2 & 11.4 & $9.8-17.5$ & 17 & 12 & 11.8 & 9.5 \\
\hline & 3 & 12.8 & $10.6-19.3$ & 19 & 15 & 13.5 & 10.8 \\
\hline & 4 & 14.9 & $11.4-18.6$ & 19 & 13 & 15.0 & 12.2 \\
\hline & 5 & 17.4 & $13.1-19.2$ & 17 & 7 & 17.3 & 13.9 \\
\hline \multirow{4}{*}{ Males } & 2 & 12.4 & $9.6-15.8$ & 20 & 14 & 12.0 & 9.2 \\
\hline & 3 & 13.5 & $10.6-17.8$ & 24 & 17 & 14.2 & 11.8 \\
\hline & 4 & 15.2 & $12.8-19.9$ & 31 & 20 & 16.0 & 13.4 \\
\hline & 5 & 18.7 & $13.7-19.4$ & 15 & 9 & 17.6 & 15.0 \\
\hline \multicolumn{8}{|c|}{ Public hair stage } \\
\hline \multirow[t]{4}{*}{ Females } & 2 & 10.9 & $9.0-14.2$ & 21 & 14 & 12.0 & 9.4 \\
\hline & 3 & 12.6 & $11.1-18.7$ & 12 & 8 & 13.5 & 10.6 \\
\hline & 4 & 14.1 & $10.4-19.3$ & 26 & 15 & 15.2 & 11.9 \\
\hline & 5 & 17.3 & $12.3-19.0$ & 18 & 11 & 19.2 & 14.7 \\
\hline \multirow[t]{4}{*}{ Males } & 2 & 12.7 & $10.3-17.5$ & 18 & 15 & 13.2 & 11.2 \\
\hline & 3 & 14.0 & $12.5-17.8$ & 16 & 14 & 14.8 & 12.5 \\
\hline & 4 & 15.1 & $13.0-19.4$ & 28 & 19 & 16.2 & 13.7 \\
\hline & 5 & 18.6 & $13.5-19.9$ & 20 & 10 & 17.9 & 15.3 \\
\hline
\end{tabular}

The age characteristics of children in each Tanner stage of sexual maturation are shown for boys and girls with SCD-SS. For comparison, published results for children with SCD-SS from the CSSCD (4) and for non-Hispanic blacks from NHANES III (13) are shown. The median age at entry represents the age at which $50 \%$ of children had entered a given Tanner stage. Obs., number of observations; No., number of children.

* Estimates of median age at entry for children with SCD are based on probit analysis of 280 observations on 78 girls and 256 observations on 70 boys.

$\dagger$ Published findings from Platt et al. (4).

$\ddagger$ Published findings from Sun et al. (13) based on the non-Hispanic black sample of the NHANES III survey, a representative sample of children in the United States.

Table 2. Anthropometric measures of growth and nutritional status, dietary intake, and hematological measures

\begin{tabular}{|c|c|c|c|c|}
\hline & $\begin{array}{c}\text { All } \\
\text { Mean } \pm \text { SD (n)* }\end{array}$ & $\begin{array}{c}\text { Girls } \\
\text { Mean } \pm \text { SD (n)* }\end{array}$ & $\begin{array}{c}\text { Boys } \\
\text { Mean } \pm \text { SD (n)* }\end{array}$ & $p$ \\
\hline Age, y & $9.1 \pm 4.7(578)$ & $8.3 \pm 4.3(300)$ & $9.9 \pm 5.0(278)$ & 0.04 \\
\hline \multicolumn{5}{|l|}{ Growth status ( $Z$ scores) } \\
\hline Weight & $-0.7 \pm 1.2(578)$ & $-0.5 \pm 1.2(300)$ & $-1.0 \pm 1.2(278)$ & 0.007 \\
\hline Length/height & $-0.4 \pm 1.0(577)$ & $-0.2 \pm 0.9(300)$ & $-0.7 \pm 0.9(277)$ & 0.04 \\
\hline \multirow[t]{2}{*}{ BMI } & $-0.7 \pm 1.2(555)$ & $-0.5 \pm 1.2(290)$ & $-0.9 \pm 1.3(265)$ & 0.19 \\
\hline & Median $(\mathrm{IQR})(n)^{*}$ & Median $(\mathrm{IQR})(n)^{*}$ & Median $(\mathrm{IQR})(n)^{*}$ & \\
\hline \multicolumn{5}{|l|}{ Nutritional status ( $\mathrm{Z}$ scores) } \\
\hline Arm circumference & $-1.0(-1.7,-0.3)(571)$ & $-0.7(-1.4,0.0)(296)$ & $-1.3(-2.0,-0.6)(275)$ & 0.001 \\
\hline Triceps skinfold & $-1.0(-1.5,-0.5)(570)$ & $-1.1(-1.5,-0.6)(295)$ & $-1.0(-1.5,-0.4)(275)$ & 0.34 \\
\hline Upper arm muscle area & $-0.4(-1.2,0.3)(570)$ & $-0.1(-0.6,0.5)(295)$ & $-0.9(-1.7,-0.1)(275)$ & $<0.001$ \\
\hline Upper arm fat area & $-1.1(-1.6,-0.6)(570)$ & $-1.1(-1.5,-0.6)(295)$ & $-1.2(-1.6,-0.6)(275)$ & 0.66 \\
\hline \multicolumn{5}{|l|}{ Dietary intake } \\
\hline Energy intake, $\mathrm{kcal} / \mathrm{d}$ & $1678(1329-2283)(391)$ & 1607 (1314-2037) (202) & $1872(1333-2414)(189)$ & \\
\hline Protein intake, $\mathrm{g}$ & $54.8(41.8-75.2)(391)$ & $51.3(40.5-65.5)(202)$ & $60.7(43.5-80.9)(189)$ & \\
\hline Energy from fat, $\%$ & $33.5(29.2,39.2)(391)$ & $32.6(27.8,38.1)(202)$ & $34.7(30.1,40.7)(189)$ & \\
\hline \multicolumn{5}{|l|}{ Hematological status $\dagger$} \\
\hline $\mathrm{Hgb}, \mathrm{mg} / \mathrm{dL}$ & $7.8(7.1-8.7)(474)$ & $8.0(7.3-9.0)(249)$ & $7.5(7.0-8.3)(225)$ & 0.01 \\
\hline Hct, $\%$ & $22.8(20.7-25.7)(475)$ & $23.9(21.5-27.0)(250)$ & $21.9(20.2-25.0)(225)$ & 0.01 \\
\hline Reticulocytes, $1000 \mathrm{~s}$ & $12.1(8.9-16.1)(472)$ & $11.4(8.2-15.9)(249)$ & $12.8(9.8-16.1)(223)$ & 0.37 \\
\hline $\mathrm{HgbF}, \%$ & $8.1(4.4-14.1)(211)$ & $10.6(5.7-15.0)(104)$ & $6.5(3.3-12.4)(107)$ & 0.002 \\
\hline Platelets, $1000 \mathrm{~s}$ & $405(331-479)(475)$ & $407(329-473)(250)$ & $398(334-490)(225)$ & 0.62 \\
\hline WBCs, $1000 \mathrm{~s}$ & $12.2(9.7-15.0)(475)$ & $12.6(9.4-15.4)(250)$ & $12.0(10.1-14.8)(225)$ & 0.93 \\
\hline
\end{tabular}

Descriptive statistics are shown for growth, nutritional status, and hematological measures for the entire sample and for boys and girls separately. The data presented are mixed longitudinal. The between-subjects SD and the total number of observations for each measure are shown. BMI $Z$ scores were calculated for children 2 y of age and older. The $p$ values are for gender comparisons adjusting for multiple observations per subject.

* Number of observations over 4 y.

$\dagger$ Excludes subjects receiving transfusion.

$\mathrm{IQR}$, interquartile range.

declined in BMI $Z$ score. Overall, $84 \%$ of children declined in one or more of these growth indicators.

Longitudinal patterns of growth. Longitudinally, length/ height and weight $Z$ scores declined with age for both males and females (Fig. 2). Among younger children, mean $Z$ scores for height and weight were close to zero (i.e. almost normal) and declined with age. Age at enrollment was negatively associated with height and weight $Z$ scores due to the age- 


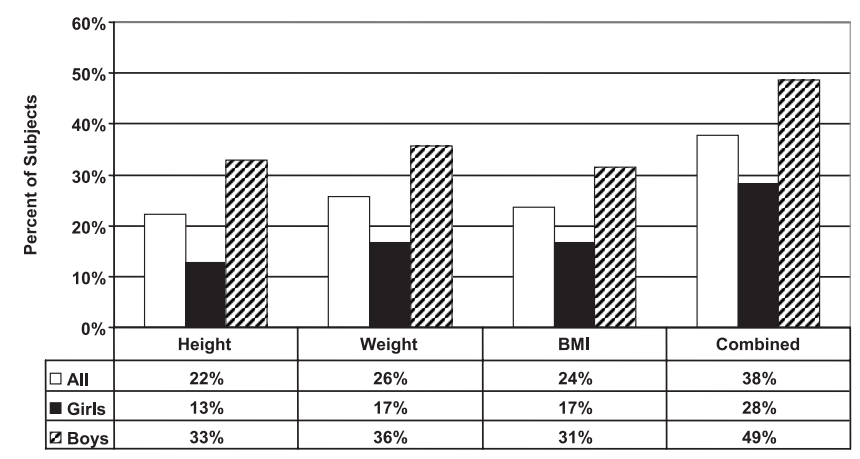

Figure 1. Prevalence of growth failure was defined as a height, weight, or BMI value below the 5th percentile compared with the Centers for Disease Control and Prevention growth charts at any time during the 4-y observation period. Results are shown for all subjects (open columns) and for girls (solid columns) and boys (hatched columns) separately as follows: The final column shows the prevalence of growth failure in any of the measures combined.

associated deficits in growth status (Table 3). Further declines in growth status occurred over time. For girls, transfusion therapy was associated with improved growth status over time, but not for boys. After adjustment for puberty stage in girls, transfusion status was not associated with changes in growth status over time (results not shown). To assess the effect of disease related parameters on growth, the analyses were restricted to nontransfused subjects only.

The results for girls are summarized as follows: length/ height and weight $Z$ scores decreased at a rate of -0.08 and $-0.05 \mathrm{Z}$ score units per year, respectively, after adjustment for the baseline age-related decline (models not shown). Addition of other factors to the model attenuated these declines. The positive and progressively increasing coefficients for Tanner stage indicated that with the advancement of puberty, height, weight, and BMI $Z$ scores improved. Hgb and Hct concentrations were positively associated with length/height $Z$ scores, and $\mathrm{Hgb}$ and $\mathrm{HgbF}$ concentrations were associated with weight and BMI $Z$ scores over time. There were no associations of reticulocyte count, platelets, SCD-related hospitalizations, maternal education, or dietary intake on length/height status in females. Nutritional status indicators (upper arm muscle area and upper arm fat area $Z$ scores) were subsequently added to the model for height $Z$ score (Table 3 ). Upper arm muscle area was positively and significantly associated with height $Z$ score over time in girls in addition to puberty status and Hgb concentration. For weight and BMI $Z$ score, the best fitting model included maternal education level, along with $\mathrm{HgbF}$, age, puberty status, and time. $\mathrm{HgbF}$ was measured in y 3-5 only, so these results are based on more limited numbers of observations. However, similar results were obtained using $\mathrm{Hgb}$, albeit with lower $R^{2}$ values $\left(R^{2}=0.30\right.$ for weight $Z$ score and $R^{2}=0.15$ for BMI $Z$ score).

For boys, age at enrollment was negatively associated with length/height and weight $Z$ scores, signaling the age-related decline in growth status that was present at baseline. After adjustment for the baseline age-related decline, height, weight, and BMI $Z$ scores declined and growth status deteriorated over time $(-0.01,-0.5$, and $-0.07 Z$ score units per year, respectively). Pubertal development was not associated with growth status, nor was transfusion status. Measures of hematological status (Hgb, Hct, HgbF, reticulocyte count, platelets, WBC counts), SCD-related hospitalizations, and dietary intake were not related to changes in growth status over time (Table 3). Upper arm muscle area $Z$ score, a nutritional status indicator, was a significant predictor of height $Z$ score and attenuated the effects of initial age and time on the longitudinal changes in height status.

\section{DISCUSSION}

Previous studies of children and adolescents with SCD were conducted up to several decades ago and demonstrated impaired growth in height and weight $(1-4,14-16)$. More recently, a survey of 63 children with SCD in Baltimore published in 1994 reported that $25 \%$ were lower than the 5th percentile for either height for age, weight for age, or weight for height (14). The longitudinal data presented here, collected from 1993 to 1999, provide insights into the pattern and magnitude of growth failure in a contemporary group of children with SCD receiving care in a comprehensive sickle
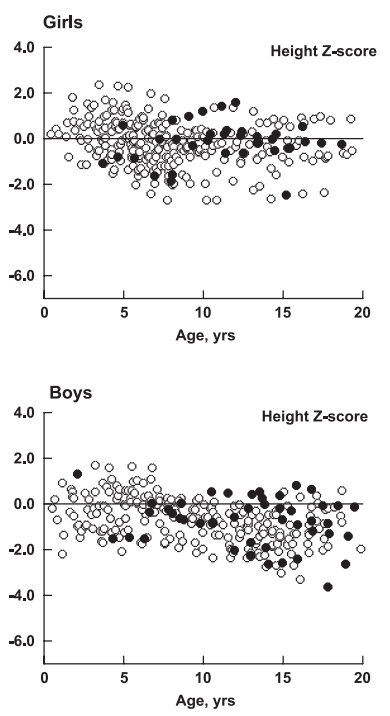
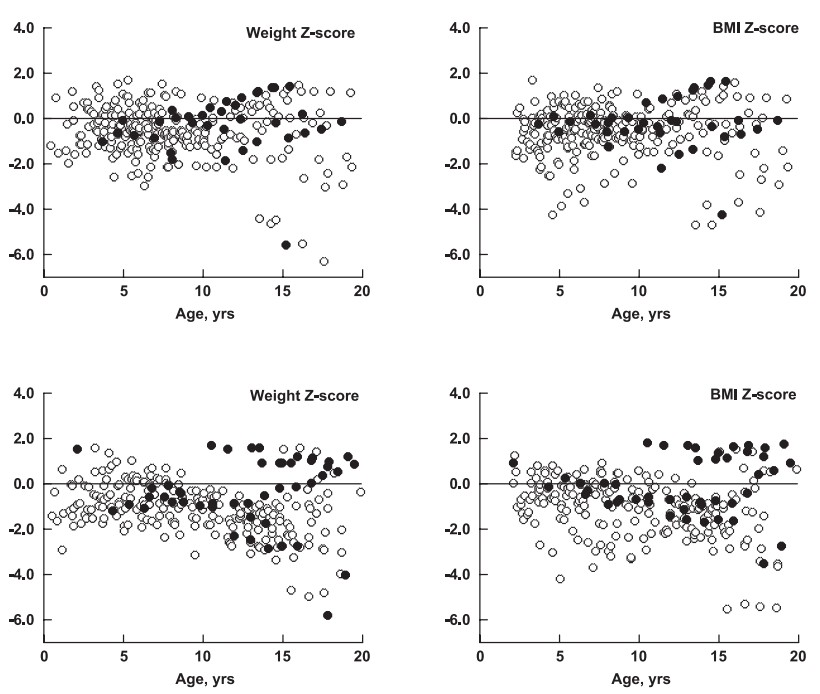

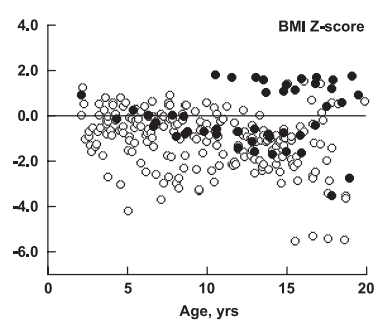

Figure 2. All observations for height, weight, and BMI $Z$ score for each subject are shown. Children receiving long-term transfusion therapy are represented by filled circles; nontransfused children are represented by open circles. The figures illustrate the age-related decline in $Z$ scores and that even children with relatively good growth status decline over time. 
Table 3. Prediction of growth status changes over time using longitudinal mixed effects regressions

\begin{tabular}{|c|c|c|c|c|}
\hline & Coefficient & SE & $p$ & Overall $R^{2}$ \\
\hline \multicolumn{5}{|l|}{ Girls } \\
\hline Length/height $Z$ score ( $n=70 ; 230$ observations) & & & & 0.40 \\
\hline Constant & 0.00 & 0.29 & 0.987 & \\
\hline Time & -0.08 & 0.02 & 0.000 & \\
\hline Tanner 2 & 0.18 & 0.11 & 0.107 & \\
\hline Tanner 3 & 0.44 & 0.13 & 0.001 & \\
\hline Hgb concentration & 0.06 & 0.03 & 0.050 & \\
\hline Upper arm muscle area $Z$ score & 0.28 & 0.04 & 0.000 & \\
\hline Weight $Z$ score ( $n=49 ; 85$ observations) & & & & 0.43 \\
\hline Constant & -1.19 & 0.50 & 0.017 & \\
\hline Initial age & -0.11 & 0.05 & 0.016 & \\
\hline Time & -0.07 & 0.03 & 0.031 & \\
\hline HgbF concentration & 0.03 & 0.01 & 0.011 & \\
\hline Maternal education level & 0.27 & 0.10 & 0.009 & \\
\hline BMI $Z$ score ( $n=49 ; 85$ observations) & & & & 0.25 \\
\hline Constant & -1.80 & 0.56 & 0.001 & \\
\hline Initial age & 0.00 & 0.05 & 0.969 & \\
\hline Time & -0.04 & 0.04 & 0.335 & \\
\hline Tanner 2 & -0.26 & 0.30 & 0.395 & \\
\hline Tanner 3 & 0.52 & 0.27 & 0.052 & \\
\hline Tanner 4 & 0.76 & 0.65 & 0.245 & \\
\hline Tanner 5 & 0.96 & 0.65 & 0.136 & \\
\hline HgbF concentration & 0.03 & 0.01 & 0.033 & \\
\hline Maternal education level & 0.26 & 0.11 & 0.020 & \\
\hline Initial age & -0.07 & 0.03 & 0.006 & \\
\hline Time & -0.05 & 0.02 & 0.001 & \\
\hline BMI $Z$ score ( $n=61 ; 218$ observations) & & & & 0.11 \\
\hline Constant & -0.23 & 0.28 & 0.420 & \\
\hline Initial age & -0.08 & 0.03 & 0.009 & \\
\hline Time & -0.07 & 0.02 & 0.007 & \\
\hline
\end{tabular}

Final models for the longitudinal mixed effects analysis predicting changes in growth status over time. Initial models were developed based on the effects of age at entry into the study to evaluate cross-sectional age effects; further declines in growth status that occurred over time after visit 1 are denoted by the variable "time" representing time since study entry. Tanner stage for breast development (girls) and genital development (boys) were entered into the models as a series of dummy variables with each stage compared to Tanner stage 1 . The effects of disease severity, dietary intake, and maternal education status were also tested among subjects who were not receiving long-term transfusion therapy. Only the final models are shown.

cell center in the United States. In this prospective study of a large sample of children with SCD-SS, $38 \%$ of subjects were below the 5 th percentile at some point during the $4 \mathrm{y}$ of the study, a commonly used screening criterion for growth failure in healthy children meriting clinical concern. However, using the criterion of failure to maintain baseline growth status, $84 \%$ of subjects experienced a decline in one or more growth indicators. The prevalence of growth failure was age dependent and worsened with age in most subjects. Thus, most children with SCD experience growth failure at some point.

Previous studies in the 1980s of young children with SCD-SS showed that at birth, infants were normal in size, but by $2-5 \mathrm{y}$ of age, significant deficits were apparent $(2,3)$, and we observed a similar pattern. In addition, our data showed that the decline was unrelenting throughout childhood and adolescence for males, especially for weight and BMI, whereas for females, growth status in length/height and weight declined during childhood and some recovery occurred with the onset of puberty. Although the sample of SCD-SS was small, Phebus et al. (1) also noted some improvement in growth status of females after age $12 \mathrm{y}$.

Delayed sexual and skeletal maturation in children with SCD $(2,4,16-19)$ was evident in this sample, as in previous samples of children with SCD, and may account, in part, for 
the observed growth deficits. The age at menarche (13.2 y) was later than the reported age in the NHANES III survey (13) for non-Hispanic black girls (mean: $12.4 \mathrm{y}, 95 \%$ confidence interval: 12.2-12.5). Compared with this survey, the median ages of children with SCD in Tanner stages 2-4 were 1-2 y older and similar to the children with SCD-SS in the CSSCD report (4). Singhal et al. (16) observed similar delays in the age at peak height velocity of boys and girls with SCD in Jamaica, another indicator of delayed pubertal development. In our study, the U.S. boys and girls with SCD-SS were comparably delayed in sexual maturation relative to national norms, but the effect of the delay on growth differed. The longitudinal regression models consistently indicated that girls experienced some growth recovery with the onset and progression through puberty, whereas for boys, there was no positive effect of puberty on growth. The reason for gender differences in the magnitude of growth deficits and the overall pattern of longitudinal changes in growth status is unknown. Others have also reported more severe growth deficits in boys with SCD compared with girls $(1,15)$. Abnormalities in gonadotropin secretion patterns (elevated luteinizing hormone and depressed follicle-stimulating hormone in early puberty) in boys and girls with SCD (19) and poor testosterone response to gonadotrophin-releasing hormone in some boys (20) suggest impairments in the regulatory feedback mechanisms of the hypothalamic-pituitary-gonadal axis leading to sexual maturity. Growth hormone abnormalities have also been reported (21-23).

Disease severity is difficult to define for SCD. SCD-related hospitalizations, long-term transfusion therapy, and measures of steady-state hematological status were used as markers of disease severity. $\mathrm{Hgb}$, Hct, and/or $\mathrm{HgbF}$ were associated longitudinally with height, weight, and BMI $Z$ scores in girls, but not boys. Girls had significantly greater Hgb, Hct, and $\mathrm{HgbF}$ than boys, and these measures were predictive of longitudinal changes in height, weight, and BMI status in girls. The reason for this gender difference is unknown. Interestingly, among prepubertal Jamaican children, Singhal et al. (24) found that Hgb concentration was associated with height and weight in males, but not females. In addition, significant improvements in linear growth were noted after splenectomy in Jamaican children (25). Evaluation of the effects of hydroxyurea therapy on growth status has not revealed a statistically significant benefit, nor an adverse effect on growth; maintenance or modest improvements in growth percentiles have been suggested $(26,27)$. In the Stroke Prevention Trial for Sickle Cell Anemia Study (STOP Trial), a well-controlled long-term transfusion therapy protocol, height, weight, and BMI $Z$ scores improved significantly in those receiving transfusions, whereas there were no changes in growth status in the control group. After 24 mo of treatment, children in the transfusion group approached normal height for age and weight for age $Z$ scores (28). We did not find an effect of transfusion therapy on changes in growth status over time, but children receiving longterm transfusion therapy had less severe bone age delay, and males had better anthropometric measures of nutritional status. In our study, the duration of transfusion therapy was not assessed, was likely variable among subjects, and was not provided under the controlled conditions of a research protocol. Therefore, this study had limited ability to assess the effects of long-term transfusion therapy on growth and sexual maturation. In sum, the longitudinal regression analyses suggest that growth status reflects the long-term effects of severe anemia, undernutrition, and other (e.g. maternal education) factors rather than the acute effects of SCD-related complications that lead to hospitalizations and long-term transfusion therapy.

Nutritional studies of children with SCD have identified numerous deficits that likely contribute to growth failure. In this study, energy, protein, and fat intake were not associated with growth failure, although a single 24-h recall of dietary intake per year is not an accurate assessment of macronutrient intake for an individual. Increased energy requirements have been reported for children, teenagers, and adults (29-31) with SCD in their usual state of health. Increased protein turnover adds an additional nutritional burden $(29,32)$. Nutrient deficiencies based on biomarkers have been reported for vitamins $\mathrm{B}_{6}(33,34), \mathrm{D}(35)$, and $\mathrm{E}(36,37)$; retinol (38); and zinc (39-41). In a 12-mo trial, zinc supplementation was shown to increase linear growth in children with SCD-SS (40). However, there are remarkably few supplementation or general nutrition intervention studies aimed at improving growth or nutritional status in children with SCD.

The findings reported here indicate that growth failure and delayed maturation remain clinically significant problems in children with SCD-SS, the more common and clinically severe form of the disease. Failure to maintain a growth trajectory was almost universal, and $38 \%$ of children fell below the 5 th percentile for weight, height, or BMI at least once during this 4-y observation period. The 5th percentile was developed as a criterion for screening healthy children for growth failure, and we suggest that is not the optimal criterion for screening children with a chronic disease with known nutritional risks. Increased energy and micronutrient requirements and endocrine abnormalities have been reported and merit future study to determine their role in the etiology and treatment of growth and developmental delay in SCD. Growth failure likely reflects malnutrition (protein, energy, and micronutrient deficits) in the growing child and adolescent with SCD and the longterm effects of severe anemia. Further research is needed to develop effective intervention strategies to achieve and maintain optimal growth and sexual and skeletal maturation in children and adolescents with SCD-SS.

Acknowledgments. The authors are grateful to the children and their families for participating in this study and thank the staff of the Comprehensive Sickle Cell Center, the General Clinical Research Center, and the Nutrition and Growth Laboratory of The Children's Hospital of Philadelphia for their time and effort.

\section{REFERENCES}

1. Phebus CK, Gloninger MF, Maciak BJ 1984 Growth patterns by age and sex in children with sickle cell disease. J Pediatr 105:28-33

2. Stevens MC, Maude GH, Cupidore L, Jackson H, Hayes RJ, Serjeant GR 1986 Prepubertal growth and skeletal maturation in children with sickle cell disease. Pediatrics 78:124-132 
3. Kramer MS, Rooks Y, Washington LA, Pearson HA 1980 Pre- and postnatal growth and development in sickle cell anemia. J Pediatr 96:857-860

4. Platt OS, Rosenstock W, Espeland MA 1984 Influence of sickle hemoglobinopathies on growth and development. N Engl J Med 311:7-12

5. Whitten CF 1961 Growth status of children with sickle cell anemia. Am J Dis Child 102:355-364

6. Lohman TG, Roche AF, Martorell R 1988 Anthropometric Standardization Reference Manual. Human Kinetics, Champaign, IL, pp 3-80.

7. Morris N, Udry JR 1980 Validation of a self-administered instrument to assess stage of adolescent development. J Youth Adolesc 9:271-280

8. Tanner JM 1962 Growth at adolescence, with a general consideration of the effects of hereditary and environmental factors upon growth and maturation from birth to maturity. 2nd ed. Blackwell Scientific Publications, Oxford

9. Schall JI, Semeao EJ, Stallings VA, Zemel BS 2002 Self-assessment of sexual maturity status in children with Crohn's disease. J Pediatr 141:223-229

10. Tanner JM, Healy MJ, Goldstein H, Cameron N 2001 Assessment of Skeletal Maturity and Prediction of Adult Height (TW3) Method. WB Saunders, London

11. Kuczmarski RJ, Ogden CL, Grummer-Strawn LM, Flegal KM, Guo SS, Wei R, Mei Z Curtin LR, Roche AF, Johnson CL 2000 CDC Growth Charts: United States. Centers for Disease Control and Prevention, National Center for Health Statistics, Hyattsville, MD

12. Frisancho AR $1981 \mathrm{New}$ norms of upper limb fat and muscle areas for assessment of nutritional status. Am J Clin Nutr 34:2540-2545

13. Sun SS, Schubert CM, Chumlea WC, Roche AF, Kulin HE, Lee PA, Himes JH, Ryan AS 2002 National estimates of the timing of sexual maturation and racial differences among US children. Pediatrics 110:911-919

14. Henderson RA, Saavedra JM, Dover GJ 1994 Prevalence of impaired growth in children with homozygous sickle cell anemia. Am J Med Sci 307:405-407

15. Modebe O, Ifenu SA 1993 Growth retardation in homozygous sickle cell disease: role of calorie intake and possible gender-related differences. Am J Hematol 44:149-154

16. Singhal A, Thomas P, Cook R, Wierenga K, Serjeant G 1994 Delayed adolescent growth in homozygous sickle cell disease. Arch Dis Child 71:404-408

17. Serjeant GR, Ashcroft MT 1973 Delayed skeletal maturation in sickle cell anemia in Jamaica. Johns Hopkins Med J 132:95-102

18. Barden EM, Kawchak DA, Ohene-Frempong K, Stallings VA, Zemel BS 2002 Body composition in children with sickle cell disease. Am J Clin Nutr 76:218-225

19. Olambiwonnu NO, Penny R, Frasier SD 1975 Sexual maturation in subjects with sickle cell anemia: studies of serum gonadotropin concentration, height, weight and skeletal age. J Pediatr 87:459-464

20. Singhal A, Gabay L, Serjeant GR 1995 Testosterone deficiency and extreme retardation of puberty in homozygous sickle-cell disease. West Indian Med J 44:20-23

21. Soliman AT, el Banna N, alSalmi I, De Silva V, Craig A, Asfour M 1997 Growth hormone secretion and circulating insulin-like growth factor-I (IGF-I) and IGF binding protein-3 concentrations in children with sickle cell disease. Metabolism 46:1241-1245

22. Soliman AT, el Zalabany M, Amer M, Ansari BM 1999 Growth and pubertal development in transfusion-dependent children and adolescents with thalassaemia major and sickle cell disease: a comparative study. J Trop Pediatr 45:23-30

23. Nunlee-Bland G, Rana SR, Houston-Yu PE, Odonkor W 2004 Growth hormone deficiency in patients with sickle cell disease and growth failure. J Pediatr Endocrinol Metab 17:601-606
24. Singhal A, Morris J, Thomas P, Dover G, Higgs D, Serjeant G 1996 Factors affecting prepubertal growth in homozygous sickle cell disease. Arch Dis Child 74:502-506

25. Singhal A, Thomas P, Kearney T, Venugopal S, Serjeant G 1995 Acceleration in linear growth after splenectomy for hypersplenism in homozygous sickle cell disease. Arch Dis Child 72:227-229

26. Zimmerman SA, Schultz WH, Davis JS, Pickens CV, Mortier NA, Howard TA, Ware RE 2004 Sustained long-term hematologic efficacy of hydroxyurea at maximum tolerated dose in children with sickle cell disease. Blood 103:2039-2045

27. Wang WC, Helms RW, Lynn HS, Redding-Lallinger R, Gee BE, Ohene-Frempong K, Smith-Whitley K, Waclawiw MA, Vichinsky EP, Styles LA, Ware RE, Kinney TR 2002 Effect of hydroxyurea on growth in children with sickle cell anemia: results of the HUG-KIDS Study. J Pediatr 140:225-229

28. Wang WC, Morales KH, Scher CD, Styles L, Olivieri N, Adams R, Brambilla D 2005 Effect of long-term transfusion on growth in children with sickle cell anemia: results of the STOP trial. J Pediatr 147:244-247

29. Badaloo A, Jackson AA, Jahoor F 1989 Whole body protein turnover and resting metabolic rate in homozygous sickle cell disease. Clin Sci 77:93-97

30. Borel MJ, Buchowski MS, Turner EA, Peeler BB, Goldstein RE, Flakoll PJ 1998 Alterations in basal nutrient metabolism increase resting energy expenditure in sickle cell disease. Am J Physiol 274:E357-E364

31. Barden EM, Zemel BS, Kawchak DA, Goran MI, Ohene-Frempong K, Stallings VA 2000 Total and resting energy expenditure in children with sickle cell disease. J Pediatr 136:73-79

32. Borel MJ, Buchowski MS, Turner EA, Goldstein RE, Flakoll PJ 1998 Protein turnover and energy expenditure increase during exogenous nutrient availability in sickle cell disease. Am J Clin Nutr 68:607-614

33. Nelson MC, Zemel BS, Kawchak DA, Barden EM, Frongillo EA, Coburn SP, Ohene-Frempong K, Stallings VA 2002 Vitamin B6 status of children with sickle cell disease. J Pediatr Hematol Oncol 24:463-469

34. Natta CL, Reynolds RD 1984 Apparent vitamin B6 deficiency in sickle cell anemia Am J Clin Nutr 40:235-239

35. Buison AM, Kawchak DA, Schall J, Ohene-Frempong K, Stallings VA, Zemel BS 2004 Low vitamin D status in children with sickle cell disease. J Pediatr 145:622627

36. Natta C, Machlin L 1979 Plasma levels of tocopherol in sickle cell anemia subjects Am J Clin Nutr 32:1359-1362

37. Natta CL, Machlin LJ, Brin M 1980 A decrease in irreversibly sickled erythrocytes in sickle cell anemia patients given vitamin E. Am J Clin Nutr 33:968-971

38. Schall JI, Zemel BS, Kawchak DA, Ohene-Frempong K, Stallings VA 2004 Vitamin A status, hospitalizations, and other outcomes in young children with sickle cell disease. J Pediatr 145:99-106

39. Leonard MB, Zemel BS, Kawchak DA, Ohene-Frempong K, Stallings VA 1998 Plasma zinc status, growth, and maturation in children with sickle cell disease. J Pediatr 132:467-471

40. Zemel BS, Kawchak DA, Fung EB, Ohene-Frempong K, Stallings VA 2002 Effect of zinc supplementation on growth and body composition in children with sickle cell disease. Am J Clin Nutr 75:300-307

41. Phebus CK, Maciak BJ, Gloninger MF, Paul HS 1988 Zinc status of children with sickle cell disease: relationship to poor growth. Am J Hematol 29:67-73 